\title{
Climate Change and Shrimp Farming in Andhra Pradesh, India: Socio-economics and Vulnerability
}

\author{
Udaya Sekhar Nagothu ${ }^{1}$, M. Muralidhar ${ }^{2}$, M. Kumaran ${ }^{2}$, B. Muniyandi², N. R. Umesh ${ }^{3}$, K. S. Krishna Prasad ${ }^{4} \&$ \\ Sena De Silva ${ }^{5}$ \\ ${ }^{1}$ Bioforsk, The Norwegian Institute for Agriculture and Environmental Research, Fredrisk A. Dahls vei 20, \\ N-1432, Ås, Norway \\ ${ }^{2}$ Central Institute of Brackishwater Aquaculture, Chennai 600 028, Tamil Nadu, India \\ ${ }^{3}$ National Centre for Sustainable Aquaculture, Kakinada 533 003, Andhra Pradesh, India \\ ${ }^{4}$ Sri M. V. K. R. Fisheries Polytechnic College, Bhavadevarapalli 521 120, Krishna District, Andhra Pradesh \\ ${ }^{5}$ Sena De Silva, Network of Aquaculture centres in Asia-Pacific (NACA) \\ Correspondence: Udaya Sekhar Nagothu, The Norwegian Institute for Agricultural and Environmental Research \\ (Bioforsk), Frederik A Dahls Vei, 20, 1432, Aas, Norway. Tel: 47-99-015-621. E-mail: usn@bioforsk.no
}

Received: December 19, 2011

doi:10.5539/eer.v2n2p137
Accepted: January 10, 2012 Online Published: October 16, 2012

URL: http://dx.doi.org/10.5539/eer.v2n2p137

\begin{abstract}
Approximately $70 \%$ of shrimp consumed globally is farmed. India is ranked among the top five shrimp farming countries globally, and occurs mainly in the eastern coastal state of Andhra Pradesh (AP). More than $90 \%$ of the farms are less than 2 ha and are farmer owned, operated and managed. The objective of this study was to increase our understanding of climatic and socio-economic factors influencing this sector, through a survey of 300 shrimp farmers in AP in 2009/10. The farming communities were divisible into two groups: members of a society/cooperative and those operating individually. The latter were large scale adopting more intensive practices. The average production cost was Indian Rupees (IRS) $80,186 \mathrm{ha}^{-1}$ and net income in summer and winter was IRS 221,901 and IRS 141,715, respectively. The mean technical efficiency estimated using Stochastic frontier function was $7 \%$ and $54 \%$. The present study attempts to explain the difference in efficiencies using socio-economic and climatic variables, the latter being a novel approach. Among socio-economic variables, farming experience and membership in society were found to have a significant influence to improve technical and economic efficiencies. Further improvements in identifiable facets of the practices and a consequent increase in technical efficiency will make the sector less vulnerable to climatic change impacts.
\end{abstract}

Keywords: climate change, shrimp farming, India, socio-economics, technical and economic efficiency, vulnerability

\section{Introduction}

Currently, nearly $70 \%$ of the shrimp consumed globally is farmed. India ranks as one of the largest producers of the black tiger shrimp [Penaeus monodon (Fabricius)] in the world. It contributed 21 and $44 \%$ by volume and value, respectively to Indian seafood exports in 2008-09 (MPEDA, 2010). The shrimp aquaculture sector in India has witnessed several changes in the last two decades:

- $\quad$ Shrimp industry in the east coast of India was seriously affected by white spot virus disease since 1993, as in most countries in the Asia-Pacific region (Kongkeo \& Davy, 2009), leading to a rapid decrease in the farming area and production volume (Muralidhar et al., 2010).

- The verdict of the Supreme Court of India in 1996, and the consequent establishment of an Aquaculture Authority (now called the Coastal Aquaculture Authority- CAA), resulted in the introduction of stringent regulations on shrimp farming, particularly in respect of location of aqua farms.

- In addition, fluctuating market prices continued to have serious impacts on shrimp exports since 1999 causing income losses to farmers in the region.

On the other hand, in the last five years or more there had been a general revival of small scale shrimp farming in India, in particular in the coastal state of Andhra Pradesh (AP) through a series of interventions. Foremost among 
these was institutional, such as the establishment of the National Centre for Sustainable Aquaculture (NaCSA), with a purview of extending the technologies to small scale farmers, and the development and adoption of better management practices (BMPs), and formation of farming clusters that have enabled more rational use of common property resources (Umesh et al., 2009).

The impact of climate change is likely to have serious influence on agriculture, fisheries, and aquaculture sectors and eventually on the food security and livelihoods of a large section of the rural population in developing countries (IPCC, 2007). India is vulnerable to climate change and extreme weather events. Several studies have shown that there is a trend of increasing surface temperature and decreasing rainfall on the Indian subcontinent (Srivastava et al., 1992; Rupakumar et al., 1994; Pant et al., 1999; Singh \& Sontakke 2002). According to Lal et al. (2001), annual mean temperature over the Indian subcontinent could increase in the range between 3.5 and $5.5^{\circ} \mathrm{C}$ by 2080s. Kumar and Parikh (2001) and Sanghi and Mendelsohn (2008) have estimated that under moderate climate change scenarios, there could be about nine per cent decline in farm-level net-revenues in India. All these studies show that India could experience warmer and wetter conditions as a result of climate change including an increase in the frequency and intensity of heavy rains and extreme climatic events.

Climate change impacts on fisheries and aquaculture is less well documented than for other primary production sectors (Cochrane et al., 2009; De Silva \& Doris, 2009). The shrimp aquaculture sector in India is dominated by small scale farmers, often defined as farmer owned/leased, operated and managed (Phan et al., 2009). Small scale farmers are often organized into clusters/cooperatives and function as a unit, especially in respect of the use of common resources such as water, harvesting and procuring supplies. The structure and functioning of these clusters have been dealt with in detail previously (Umesh et al., 2009).

The objective of the present study is to increase our understanding of socio-economic and climatic factors influencing the shrimp farming sector, in AP, India. The present study also attempts to explain the different technical and economic efficiencies of shrimp farmers using socio-economic and climatic variables. The inclusion of climatic variables is a novel approach adopted in this analysis. It is expected that the finding of this study will provide suitable adaptive and mitigating measures to combat climate change impacts on the shrimp farming sector.

\section{Definition of Concepts}

The impacts of climate change on shrimp farming could occur directly or indirectly and cannot be attributed to one single factor of climate change, as in the case of many aquaculture practices (De Silva \& Doris, 2009). Changes in average precipitation, potential increase in seasonal and annual variability and extremes are likely to be the most significant drivers of climate change on shrimp aquaculture. Variability in the amount of rainfall under different monsoon scenarios could also negatively impact shrimp aquaculture. Decrease in the salinity (Preston et al., 2001), algal blooms, depletion of dissolved oxygen particularly in summer months when water exchange becomes difficult in inland and coastal areas of brackishwater shrimp ponds can significantly impact farm production. The production efficiency of tropical and sub-tropical species of farmed shrimp, such as $P$. monodon and Feneropenaeus merguiensis (De Man) can be increased by a rise in water temperature (Jackson \& Wang 1998). On the other hand, increased temperatures will affect pond evaporation rates and the resultant increases in pond salinity could adversely affect less salt-tolerant species. The negative impacts of high temperatures for aquaculture on water quality in source water bodies could also increases the intensity and frequency of disease outbreaks (Goggin \& Lester, 1995; Harvell et al., 2002; Vilchis et al., 2005). Increase in the intensity and/or frequency of extreme climatic events cause damage to infrastructure and shrimp stocks (Muralidhar et al., 2009; Ponniah \& Muralidhar, 2009) and the associated negative impacts, changes in salinity of pond water and introduction of disease or predators into aquaculture facilities along with the flooded water would result in crop losses. Sea level rise leads to the subsequent inundation of coastal lands that could cause reduced area for aquaculture and availability of more area for brackish water aquaculture in certain geographical locations (Pillai \& Muralidhar, 2006).

\subsection{Vulnerability to Climate Change}

Vulnerability is a function of exposure, that is, the character, magnitude, and rate of climate variation to which a system is exposed and its sensitivity to exposure. The latter is the extent the system changes under the exposure and its adaptive capacity. Vulnerability depends critically on context, and the factors that make a system vulnerable to a hazard, will depend on the nature of the system and the type of hazard in question. Vulnerability is also described as the extent to which a system is susceptible to sustaining damage from climate change (Schneider et al., 2001). It can be considered as a dynamic state or condition that is influenced by both biophysical and socioeconomic conditions (Dow, 1992; Bohle et al., 1994; Kasperson et al., 2001; Liverman, 
2001).

\subsection{Shrimp Farming in Andhra Pradesh (AP), India}

The potential area available for brackish water aquaculture in AP is about 150,000 ha with a network of 172 brackish water bodies in 9 coastal districts (Aquaculture Authority, 2001). This accounts for $12.6 \%$ of the total potential area in the country (1.2 million ha). Out of total potential area in AP, 84,951 ha (56.6\%) has been developed for shrimp farming (MPEDA, 2006). Shrimp farming is largely dependent on small holdings of less than 2 ha; these farms account for $90 \%$ of the total area utilized for shrimp culture, $7 \%$ of farms being between 2 and 5 ha and the remainder an area of greater than 5 ha (Yadava, 2002; MPEDA, 2006).

Ancillary units such as feed mills, hatcheries and diagnostic labs have been developed to support the industry, thus boosting regional and local economies. There were 191 hatcheries in 2006 in AP with a production capacity of 9,335 million shrimp post larvae (PL) per year and the number of feed mills was 25 .

\subsection{Shrimp Farmer Societies}

The shrimp farmer associations in AP began as a part of an initiative to reduce the impact of shrimp disease through the implementation of better management practices (BMPs) in small-scale farming clusters. The initiative was established under a cooperative program between the Marine Products Export Development Authority (MPEDA) and the Network of Aquaculture Centers in Asia-Pacific (NACA). Over the last few years this has brought about a revival of small-scale tiger shrimp farming in AP and other coastal states of India (Umesh et al., 2009). It has also led to policy and institutional change within India, culminating in the formation of the National Centre for Sustainable Aquaculture (NaCSA). NaCSA has organized 386 societies as of 31 December 2009 with a membership of 25 to 50 registered farmers in each society in five coastal districts of AP alone. AP produces almost $50 \%$ of the farmed shrimp in India and there are about 8,885 registered farmers involved in these societies, and the total area under shrimp farming was 8,633 ha (NaCSA, 2009).

\subsection{Climate Change Scenarios in Andhra Pradesh (AP)}

According to a World Bank report on "The impact of climate change on India", dry land farmers' income in AP will plunge by 20 per cent $(\mathrm{FAO}, 2009)$. Under a modest to harsh climate change scenario of a substantial rise in temperatures $\left(2.3^{\circ} \mathrm{C}\right.$ to $\left.3.4^{\circ} \mathrm{C}\right)$ and a modest but erratic increase in rainfall $(4$ to $8 \%)$ it is predicted that incomes of small scale farmers could decline by as much as $20 \%$ (FAO, 2009). The state of AP in India has the longest coastline in the country. The AP coast is known for its frequent tropical cyclones and associated floods and tidal surges causing loss of life and property in the region (Bastia \& Nayak, 2006). In the last decade alone, the state experienced 18 devastating storms causing enormous loss of life and property. The AP coast is also prone to tsunamis especially the low lying zones along the Krishna and Godavari deltas (Nageswara et al., 2007). The year 2007 was the fourth warmest year in AP on record since 1901 after, 2002, 2006 and 2003 (IMD, 2008). During 2009, heat wave conditions also prevailed over parts of coastal AP during the second fortnight of May. Even in October 2009, temperatures were soaring when there should be a chill in the air (IMD, 2009).

Climate change and associated sea-level rise (SLR) is one of the major environmental concerns of today. SLR is likely to further intensify storm surges (Pendleton et al., 2004), besides accelerating shoreline erosion and other problems like seawater intrusion and damage to coastal structures, thereby making the AP coast much more vulnerable in the future. About $43 \%$ of the $1,030-\mathrm{km}$-long AP coast is considered as very high risk. It is predicted that if the sea level rises by $\sim 0.6 \mathrm{~m}$ it will displace more than 1.29 million people living within $2.0 \mathrm{~m}$ elevation in 282 villages in the region (Nageswara et al., 2008). Notably, the inhabitants of these villages are mainly hut-dwelling fishing communities who are highly vulnerable in socio-economic terms as well. Further, there is every possibility of increased storm surges (Unnikrishnan et al., 2006) that would reach much further inland than at present with a rise in sea level. In addition to SLR, floods, droughts, and cyclones are the main extreme natural events in tropical Asia. Any increase in the intensity and/or frequency of extreme climatic events can damage aquaculture (Muralidhar et al., 2009; Ponniah \& Muralidhar, 2009)

\section{Materials and Methods}

\subsection{Study Area}

Andhra Pradesh has a long coastline with two large delta systems formed by the rivers Godavari and Krishna that offers a great potential for aquaculture sector, with the largest number of shrimp farms, mostly small-scale and has the highest number of shrimp farming societies. Within AP, Krishna district was chosen as the study area since it has the maximum potential shrimp farming area in the state (Figure 1). 


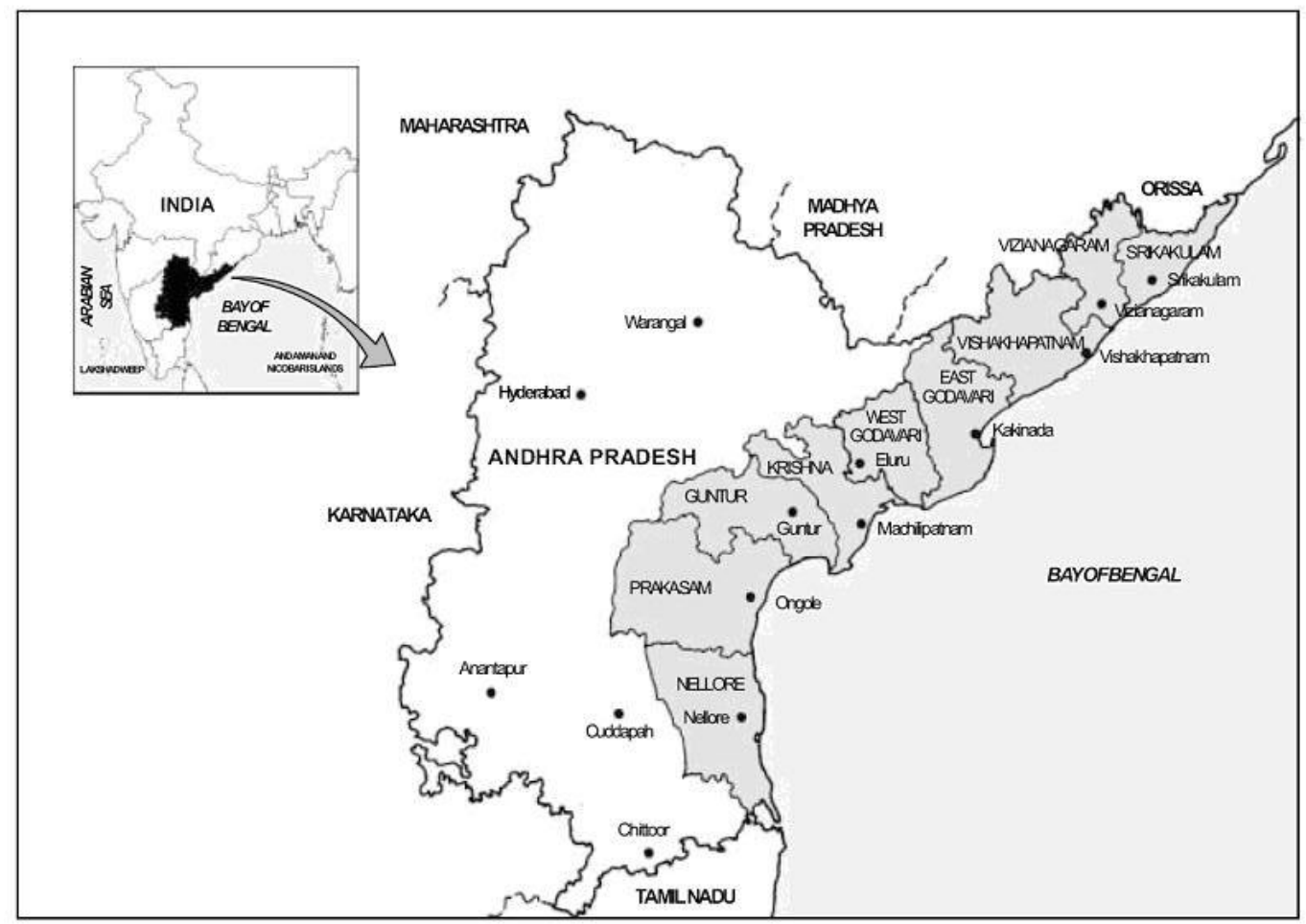

Figure 1. Map of Andhra Pradesh showing coastal shrimp growing districts (Arrow shows the location of study area: - Latitude: $15^{\circ} 43^{\prime} \mathrm{N}$ and $17^{\circ} 10^{\prime} \mathrm{N}$ and Longitude: $80^{\circ} 0^{\prime}$ and $81^{\circ} 33^{\prime}$ of E)

A total of 300 farmers were surveyed in 2009-2010 (243 society farmers and 57 non-society farmers), from inland and coastal areas in four mandals (sub-district administrative unit) of the district viz., Machilipattinam, Bantumilli, Koduru and Nagayalanka of Krishna district. This was approximately $10 \%$ of the total population of shrimp farmers, selected based on stratified random sampling. The farmers were interviewed using a pre-tested structured survey questionnaire that included socio-economic, farm and production details, perception of farmers to climate change events and their adaptive capacity. These farm surveys were supplemented with discussion group meetings when the information was verified further and where needed authentication obtained. Finally, the summary results were presented to stakeholder groups for further verification and authentication.

\subsection{Data Analysis}

In addition to descriptive statistics, a Stochastic Frontier Function and Cobb Douglas function were used to study the technical and economic efficiencies of the farmers, respectively. The present study attempts to explain the difference in efficiencies using socio-economic and climatic variables. Inclusion of climatic variables is a novel approach in this analysis.

The technical efficiencies were computed by fitting 'Stochastic frontier function' to the data on inputs and the output. A brief discussion of this methodology is given below:

Let us assume that each farm uses $m$ inputs (vector $x$ ) and produces a single output $y$. Following Aigner et al. (1977) and Meeusen and van den Broek (1977), it can be assumed that the production technology of the $i^{\text {th }}$ farm is specified by the stochastic frontier production function

$$
y_{i}=f\left(x_{i} ; \beta\right) \exp \left(\varepsilon_{i}\right)
$$

where $i=1,2, \ldots, n$ refers to farms, $\beta$ is a vector of parameters and $\varepsilon_{i}$ is an error term and the function $f(x ; \beta)$ is called the 'deterministic kernel'. The frontier is also called as 'composed error' model because the error term $\varepsilon_{i}$ is assumed to be the difference of two independent elements,

$$
\varepsilon_{i}=v_{i}-u_{i}
$$

where $v_{i}$ is a two sided error term representing statistical noise such as weather, strikes, luck etc which are beyond the control of the farm and $u_{i} \geq 0$ is the difference between maximum possible stochastic output (frontier) $f\left(x_{i} ; \beta\right) \exp \left(v_{i}\right)$ and actual output $y_{i}$. Thus $u_{i}$ represents output oriented technical inefficiency. Thus the error term $\varepsilon_{i}$ has an asymmetric distribution. From (1) and (2), the farm-specific output-oriented technical 
efficiency is given by

$$
T E_{i}^{o}=\exp \left(-u_{i}\right)=y_{i} /\left\{f\left(x_{i} ; \beta\right) \exp \left(v_{i}\right)\right\}
$$

Since $u_{i} \geq 0,0 \leq \exp \left(-u_{i}\right) \leq 1$ and hence $0 \leq T E_{i}^{o} \leq 1$. When $u_{i}=0$ the farm's output lies on the frontier and it is $100 \%$ efficient. Thus the output oriented technical efficiency tells how much maximum output is possible with the existing usage levels of inputs. The estimation of stochastic production frontier function may be viewed as a variance decomposition model. The variance decomposition can be expressed as:

$$
\sigma^{2}=\sigma_{u}^{2}+\sigma_{v}^{2}
$$

And

$$
\gamma=\frac{\sigma_{u}^{2}}{\sigma_{u}^{2}+\sigma_{v}^{2}}
$$

In the literature the common functional forms used to represent the deterministic kernel are 'Cobb-Douglas' and 'Translog'. The 'Cobb-Douglas' function in log form can be stated as

$$
\ln \left(y_{i}\right)=X_{i} \beta+v_{i}-u_{i}, i=1,2, \ldots n
$$

where $X_{i}$ is a vector consisting of the logarithms of $m$ inputs. Maximum Likelihood Estimation procedure is followed to estimate the frontier production function. In the present study the Cobb-Douglas function was used with the following variables:

$$
\text { Dependent Variable: } \mathrm{Y}=\text { yield of shrimp in } \mathrm{kg}
$$

Independent Variables: Feed quantity (kg), Hired labour (days), Seed quantity (in '000s), Pond preparation cost and Fuel and other costs (all in Indian Rupees).

\section{Results and Discussion}

\subsection{Socio-economic Status of Shrimp Farmers}

In the study all farmers cultivated tiger shrimp (P. monodon). The average household size for the sample was $\approx 5$ (range 1-12). Also there was little difference in the average household size between the four different mandals. The average ratio of male to female members was approximately 5:4 in the households. On average, nearly half of the family members $(45 \%)$ were engaged in farm activities, indicating that family labour is an important contributor to shrimp farming. Out of the 300 farmers surveyed, $264(88 \%)$ were owners and the rest were caretakers, and farming experience averaged 14 years (range 2-20 years). Table 1 provides the distribution of occupation and experience in aquaculture mandal wise.

Table 1. Distribution of farmers' occupation and years of farming experience across the study area

\begin{tabular}{lcccccccccc}
\hline \multicolumn{1}{c}{ Mandal/ total } & \multicolumn{4}{c}{ Main Occupation } & \multicolumn{4}{c}{$\begin{array}{c}\text { Years of } \\
\text { experience }\end{array}$} & \multicolumn{3}{c}{$\begin{array}{c}\text { Society } \\
\text { Member }\end{array}$} \\
\hline Mandal & No. & $\begin{array}{c}\text { Shrimp } \\
\text { only }\end{array}$ & $\begin{array}{c}\text { Shrimp and } \\
\text { Fishing }\end{array}$ & $\begin{array}{c}\text { Shrimp and } \\
\text { Agicult }\end{array}$ & $\begin{array}{c}\text { Shrimp/ Fishing } \\
\text { and Agricul }\end{array}$ & $<5$ & $5-10$ & $>10$ & Yes & No \\
Machilipatnam & 85 & 70 & 9 & 5 & 1 & 7 & 17 & 61 & 77 & 8 \\
Bantrunulli & 35 & 32 & 0 & 3 & 0 & 4 & 4 & 27 & 20 & 15 \\
Koduru & 80 & 57 & 23 & 0 & 0 & 11 & 23 & 46 & 66 & 14 \\
Nagayalanka & 100 & 88 & 8 & 3 & 1 & 9 & 26 & 65 & 80 & 20 \\
Total & 300 & 247 & 40 & 11 & 2 & 31 & 70 & 199 & 243 & 57 \\
\% of Total & 100 & 82 & 13 & 4 & 1 & 10 & 24 & 66 & 81 & 19 \\
\hline
\end{tabular}

About $41 \%$ of the farmers sampled were educated up-to primary level, $27 \%$ up to secondary level, $8 \%$ up to university level and the remainder had no formal education. Overall, 83\% (250) of the farmers had undergone at least one training course related to aquaculture and the rest had not been through any form of training. A vast majority ( $82 \%$ ) of the farmers has shrimp farming as the main occupation and $13 \%$ have both shrimp cultivation and fishing (Table 1). Almost $81 \%$ of the farmers have membership in an aquaculture society, NaCSA. The great 
bulk of non-members were large scale farmers who practice intensive shrimp culture.

The analysis also revealed that on an average $46 \%$ family members were earning members. Out of those who earn, $63 \%$ (or $29 \%$ of the total sample size) were males (Figure 2). It is thus important to address both genders, while devising strategies or programs for improving their adaptive capacity.
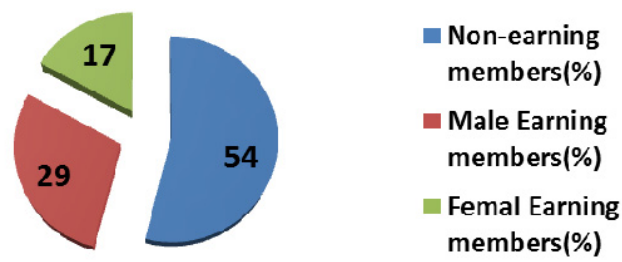

Figure 2. Percentage of earning and non-earning members among sampled farmers

\subsection{Shrimp Farming and Production Economics}

Table 2 presents the economic analysis of shrimp farming during summer and winter crops and the annual combined costs for the two crops. The findings reveal that average cost, gross and net incomes during summer season was much higher than that in winter. The average production cost per ha during summer was IRS 80,186 (US $\$ 1$ = IRS 44.00) whereas the corresponding figure for winter was IRS 12,717. It is obvious, since, summer season is the main cropping season, and hence major investments for land preparation etc, occur in this season. The average annual cost of production per ha was IRS 92,903. The annual gross income (ha ${ }^{-1}$ ) from shrimp farming in AP was IRS 245,269 and the net income was IRS 152,366.

Table 2. Per hectare cost and income (in IRS; US $\$ 1=$ IRS 44.00) of shrimp farming in study area (Summer crop: Feb/March to June/July; Winter crop: Aug/Sep to Nov/Dec)

\begin{tabular}{llll}
\hline Inputs & Summer crop & Winter crop & Annual average \\
\hline Costs & & & \\
Pond Preparation & 9729.2 & 2289.9 & 12019.0 \\
Fertilizer & 46.7 & 33.9 & 80.6 \\
Feed & 40920.9 & 5395.3 & 46316.2 \\
Drugs & 426.5 & 121.5 & 548.0 \\
Fuel (diesel) & 18123.0 & 3253.7 & 21376.7 \\
Electricity & 276.0 & 66.0 & 342.0 \\
Labour & 804.0 & 151.3 & 955.3 \\
Seed & 9859.7 & 1405.3 & 11265.0 \\
Total production cost & 80185.9 & 12717.0 & 92902.8 \\
\hline Income & & & \\
Gross & 221901.3 & 23367.7 & 245269.0 \\
Net & 141715.4 & 10650.7 & 152366.2 \\
\hline
\end{tabular}

The percentage break down of the various costs during summer, winter and the average for the year are shown in Table 2. Cost of feed was the major share accounting for $50 \%$ of the total costs. Fuel is the next item with a share of $23 \%$ followed by pond preparation (13\%) and seed (12\%) and the rest $(2 \%)$ which includes cost of labour, fertilizer and electricity. 


\subsection{Society and Non-society Farmers}

Table 3 presents the average net income of the society and non-society farmers in different mandals for the two crops. In all the mandals the average income $\left(\mathrm{ha}^{-1}\right)$ of the non-society farmers was much higher than those of society farmers for both crops. Between the mandals, non-society members of Koduru mandal had the highest income. A non-society farmer earned a net income of IRS 170,502 as compared to a society farmer's income of 75,051 . This can be explained by the fact that, most society farmers were small scale, and following extensive and semi-extensive methods of cultivation, as compared to non-society farmers who were operating larger sized farms, and practise intensive farming. NaCSA is attempting to improve the skills of society farmers, who mostly operate on a small scale. Farmers need help in terms of quality seed, feed and fuel optimization, and subsidy on inputs, especially in the periods when they are affected by extreme weather events. Shrimp farmers are not covered by any crop insurance schemes, as compared to farmers cultivating rice or other crops. It is small farmers who are more vulnerable in the event of extreme weather events and also to the long term effects of climate change. They are in a majority, and if their livelihoods have to be protected, priority should be given to improve their adaptive capacity.

Table 3. Per ha net income (IRS) (Average values with \pm standard deviation) of Society and Non-Society farmers in different mandals in different crops (Summer crop: Feb/March to June/July; Winter crop: Aug./Sep. to Nov./Dec.)

\begin{tabular}{llccccc}
\hline \multirow{2}{*}{ Season } & Category & \multicolumn{5}{c}{ Mandal } \\
\cline { 3 - 7 } & & Machilipattnam & Bantumulli & Koduru & Nagayalanka & Combined \\
\hline \multirow{2}{*}{ Summer crop } & Society & $44866 \pm 22625.4$ & $59149 \pm 43461.5$ & $81686 \pm 50593.1$ & $68514 \pm 45167.7$ & $65465 \pm 43904$ \\
& Non-Society & $136279 \pm 75967.4$ & $173640 \pm 99201.3$ & $194137 \pm 141682.1$ & $150047 \pm 90025.3$ & $159601 \pm 105675.4$ \\
& Combined & $125772 \pm 77547$ & $128538 \pm 98887.6$ & $174458 \pm 137063.7$ & $133740 \pm 89068.4$ & $141715 \pm 103768$ \\
& Society & $4276 \pm 8454$ & $7940 \pm 11090.7$ & $1140 \pm 11014.5$ & $19224 \pm 8145.4$ & $9586 \pm 11014.5$ \\
Winter crop & Non-Society & $14548 \pm 10671.6$ & $14112 \pm 10181.3$ & $8603 \pm 17268.5$ & $8482 \pm 11333.2$ & $10900 \pm 13061.9$ \\
& Combined & $13367 \pm 22841.2$ & $11680 \pm 20943.5$ & $7297 \pm 20808$ & $10631 \pm 20905.1$ & $10651 \pm 21479.6$ \\
& Society & $49142 \pm 28248.3$ & $67089 \pm 42163.8$ & $82825 \pm 50176.5$ & $87737 \pm 50687.8$ & $75051 \pm 46610.6$ \\
Annual & Non-Society & $150827 \pm 80931$ & $187752 \pm 92987.3$ & $202741 \pm 143103.3$ & $158529 \pm 91668$ & $170502 \pm 107042.1$ \\
& Combined & $139139 \pm 83281.6$ & $140217 \pm 96878$ & $181755 \pm 139162.1$ & $144371 \pm 89489.9$ & $152366 \pm 105297$ \\
\hline
\end{tabular}

\subsection{Climate Change Events Perceived by Farmers in the Study Area}

Shrimp farmers in both inland and coastal areas experienced similar climate change (CC) events viz., irregular season (IRS), high temperature (HTEM), cyclones (CYC), heavy rains (HR), flood (FLD) and drought (DRT) though there was a difference in the order of severity. The observations on type of CC and associated impacts indicated that cyclones and floods were perceived by all the categories of farmers and IRS, HTEM, HR and DRT, were perceived by 236, 267, 272 and 177 farmers, respectively. However, the magnitude of perception order was HR $>$ HTEM > IRS > DRT for society, non-society and coastal farmers, whereas HTEM preceded the HR for inland farmers. There was a significant difference among the $\mathrm{CC}$ events and impacts with respect to their likelihood occurrence. DRT comes under one group with low average score of around 2.5. FLD and HTEM were highest likelihood events with average scores of 4.5 and 4.6, respectively. A similar trend was observed with society, non society, coastal and inland farmers. Coastal farmers rated cyclone also as the most likelihood occurrence along with HTEM and FLD. Society and non-society farmers rated HTEM as the most likelihood CC event. There was a significant difference in the consequence rating between the CC events. DRT, IRS and HTEM were of less consequence to shrimp farming compared to CYC, FLD and HR. In coastal and inland areas also a similar trend was observed, but CYC and FLD resulted in more damage than HR. Society and non society farmers also reported the same type of consequence of $\mathrm{CC}$. The highest risk rating climate change event was floods followed by cyclone. 


\subsection{Technical Efficiency of Shrimp Farmers}

The estimated parameters of the production functions are given in Table 4. It shows that feed has a significant contribution to yield. Feed also occupies a major part of the input costs. It was also observed during the field visits that there is a lack of adequate knowledge on the optimim feeding schedules. Excess feeding also results in wastage, increased costs to farmers and pollution of water bodies. All the other inputs were found to be non-significant. The value of $\gamma$, the ratio of variance due to inefficiency to the total variance was significant $(P<0.05$ : Table 4).

Table 4. Maximum-likelihood estimates of the stochastic Cobb-Douglas production frontier function

\begin{tabular}{lll}
\hline Variable & Coefficient & t-value \\
\hline Intercept & 1.6552 & 1.70 \\
Log (Feed) & 0.7296 & $2.0384^{* *}$ \\
Log (Hired labour) & 0.0025 & 0.0030 \\
Log (Seed) & 0.3179 & 0.4519 \\
Log (Pond preparation cCosts) & -0.2049 & -0.2328 \\
Log (Fuel and other costs) & 0.0728 & 0.0861 \\
$\gamma$ & 0.9913 & $1.931^{* *}$ \\
$\sigma^{L}$ & 0.0382 & 0.6612 \\
Log-likelihood & 226.3 & \\
\hline
\end{tabular}

Source: Farmers surveys conducted in 2009-2010 in Krishna district of Andhra Pradesh.

$* *$ Significant at $5 \%$ level.

The fitted frontier model was then used in equation (3) to estimate the efficiencies of the individual farmers. The mean technical efficiency was estimated to be $87 \%$ implying that on the average farmer is producing $87 \%$ of the maximum possible output.

It is evident from Table 5 (frequency distribution of the efficiencies) that about $54 \%$ of the farmers are more than $90 \%$ efficient. The high efficiency may be attributed to the use of better quality feed, seed stock and adoption of latest technology in farming. However, a majority of these constitute large farmers who were carrying out intensive and semi-intensive method of cultivation. Whereas, small scale farmers mostly practise extensive method of cultivation.

Table 5. Frequency distribution of the efficiencies of the farmers

\begin{tabular}{ccc}
\hline Range & Frequency & Farms (\%) \\
\hline$>90$ & 163 & 54.3 \\
$80-90$ & 80 & 26.7 \\
$70-90$ & 1 & 0.3 \\
$60-70$ & 50 & 16.7 \\
$<60$ & 6 & 2.0 \\
\hline
\end{tabular}

As already stated, technical efficiency measures the efficiency in utlization of resources. A $100 \%$ technically efficient farm will lie on the frontier and it produces maximum possible output using all the resources in an optimal way. Many authors (Timmer, 1971; Muller, 1974; Kalirajan \& Shand, 1989) have suggested that the discrepancies in efficiencies can be explained by regressing technical efficiency with the socio-economic and demographic factors of the individual farmers. But in the present study, since some farmers were using different adaptation strategies to overcome the negative effects of climate change, it was considered more pertinent to include the effect of the various strategies also along with socio-economic factors. This will help to determine whether the strategies of the farmers to climate change really help in improving their efficiencies. Accordingly, 
the variables used in the regression equation thus developed are given in Table 6.

Table 6. Dependent and independent variables impacting the technical efficiency of individual farmers

\begin{tabular}{ll}
\hline Socio-economic variables & Climatic variables \\
\hline Stocking density & Cyclone Storm -Level of Success (CYCLS) \\
Farming experience in years (FEXPYR) & Flood from rain - Level of Success (FLDLS) \\
Water spread area & Irregular Season Observation (IRSOBSV) \\
Education level (REPEDU) & Observation of Low temperature change (LTEMOBS) \\
Trainings undergone or not(TRNATTND) & Drought Observation (DRTOBS) \\
Member of Society or not (Society=1; & Water salinity increase observation (WSIOBS) \\
Non-society=2) (SOCNSOC & \\
\hline
\end{tabular}

The climatic variables were selected from a list to which farmers responded in the survey. The estimated parameters of the regression model are presented in Table 7 . The high $\mathrm{R}^{2}$ values indicate the adequacy of the model. Among socio-economic variables, stocking density, farming experience and society membership has significant influence on the efficiencies. The coefficient of the SOCNSOC is significant and positive indicating that non-society members were more efficient than society members. This was also supported from the values of net income of non-society members which was much higher than those of society members (Table 4). This is also justified by the fact that most non society members were large sale farmers. All other socio-economic variables were not significant although their coefficients have a positive sign.

Table 7. Efficiency differentials across shrimp farmers in the study area. Note that abbreviations for independent variables in Table 6 are used here also

\begin{tabular}{lccc}
\hline & Coefficients & Standard Error & $t$ Stat \\
\hline Intercept & 0.33707 & 0.01967 & 17.140 \\
Water spread area & -0.00250 & 0.00316 & -0.791 \\
Stocking density & 0.00215 & 0.00110 & $1.958^{*}$ \\
FEXPYR & 0.00073 & 0.00041 & $1.771^{*}$ \\
REPEDU & 0.00050 & 0.00260 & 0.193 \\
TRNATTND & 0.00269 & 0.01534 & 0.175 \\
SOCNSOC & 0.27589 & 0.01467 & $18.805^{* * *}$ \\
CYCLS & 0.01641 & 0.00484 & $3.393^{* * *}$ \\
FLDLS & 0.01238 & 0.00475 & $2.607^{* * *}$ \\
IRSOBSV & 0.00575 & 0.00550 & 1.046 \\
LTEMOBS & 0.00073 & 0.00496 & 0.146 \\
DRTOBS & -0.00180 & 0.00460 & -0.391 \\
WSIOBS & -0.00496 & 0.00495 & -1.001 \\
$\mathrm{R}^{2}$ & 0.895 & & \\
F-statistic & 203.9 & & \\
\hline
\end{tabular}

*Significant at $10 \%$ level; *** Significant at $1 \%$ level.

Among the climatic variables, cyclone storm - level of success and flood from rain - level of success, were the only two variables which were significant. Further the coefficients of these variable were positive indicating that those farmers who had successfully overcome the negative effect of cyclone storm and floods have increased their efficiency levels. All other climate variables were found to be non-significant. 


\section{Conclusions and Recommendations}

The east coast of India and especially the Andhra Pradesh (AP) state is highly vulnerable to extreme weather events, including cyclones, floods, in addition to likely changes in temperature, sea-level rise and change in monsoon patterns. The shrimp farming sector and small scale farms that dominate the sector in AP are vulnerable to the climate changes. Measures need to be taken to reduce the vulnerability and improve adaptive capacity of the small scale farmers:

- Feed and fuel contributed to two-thirds of the input costs. Hence it is important to train the farmers on optimum feeding schedules, and fuel use and conversion to electricity instead of the dependenace on more expensive fuel, in order to improve the technical and economic efficiency. As far as feed is considered, research efforts need to be intensified to develop low fish meal feed technology using plan protein sources and popularization of this feed technology among the farming communities.

- $\quad$ Non society farmers are relatively big farmers (above 2 ha size) hence they stock more, had professional consultants to gain advice, do more management measures and get higher production. Big farmers do have the capacity to electrify their farms which helped them in reducing the production cost. To reduce the dependency on diesel fuel farmers may be provided with electricity at reduced tariffs.

- Cyclone and flood are the two critical climatic events perceived as threats to the shrimp farming in the study area. Hence, farmers need to be given advanced warnings on cyclones and floods. Farmers need to be trained on farm management measures to be followed during such occasions. Institutional credit support may be provided to the farmers from the calamity mitigation programmes to prepare themselves to enhance their capacity to deal with these extreme climatic events. Hence, more small scale farmers should be encouraged to become members of NaCSA, as it could protect the farmers by provding better services and information, and help them during extreme weather events.

- During the winter farmers may be farming fin fishes if adequate quantity of seed is available. Efforts may be made for supply of finfish seeds to the farmers during the winter time. This reduces their risks and vulnerability since fin fish could withstand the variations in soil and water quality parameters due to climatic events.

- It is important to address both women and men, while devising strategies or programs for improving their adaptive capacity.

- The skill sets of small scale farmers should be improved to help them more towards semi-intensive method of cultivation.

- Since majority of the farmers were of a relatively low literacy background, the capacity building programmes need to be on 'learning by doing mode' and should be in local language. Pictorial guides and posters would enhance their understanding.

\section{Acknowledgements}

The authors wish to thank Norwegian Agency for Development Cooperation (Norad) for funding support to conduct the research (2009-2012), a program coordinated by the Network of Aquaculture Centres in Asia-Pacific (NACA). We are most grateful to the numerous farmers who very willingly cooperated in the surveys and were very forthcoming with information.

\section{References}

Aigner, D. J., Lovell, C. A. K., \& Schmidt, P. J. (1977). Formulation and estimation of stochastic frontier production function models. Journal of Econometrics, 6, 21-37. http://dx.doi.org/10.1016/0304-4076(77)90052-5

Aquaculture Authority of India. (2001). Shrimp Aquaculture and the Environment: An Environment Impact Assessment Report submitted to the Supreme Court of India. Aquaculture Authority, Government of India, p. 114.

Bastia, R., \& Nayak, P. K. (2006). Tectonostratigraphy and depositional patterns in Krishna offshore basin, Bay of Bengal. The Leading edge, 25, 839-845. http://dx.doi.org/10.1190/1.2221361

Bohle, H. G., Downing, T. E., \& Watts, M. J. (1994). Climate change and social vulnerability. Global Environmental Change, 4, 37-48. http://dx.doi.org/10.1016/0959-3780(94)90020-5

Cochrane, K., de Young, C., Soto, D., \& Bahri, T. (2009). Climate change implication for fisheries and aquaculture. Overview of current scientific knowledge. FAO Fisheries and Aquaculture, Technical Paper, 
530, FAO, Rome, p. 212.

De Silva, S. S., \& Doris, S. (2009). Climate change and aquaculture: potential impacts, adaptation and mitigation. In: Climate change implication for fisheries and aquaculture. Overview of current scientific knowledge FAO Fisheries and Aquaculture Technical Paper 530 (ed. by Cochrane K., de Young C., Soto D., \& Bahri, T.). FAO, Rome, pp. 151-212.

Dow, K. (1992). Exploring differences in our common future(s): the meaning of vulnerabilityto global environmental change. Geoforum, 23, 417-436. http://dx.doi.org/10.1016/0016-7185(92)90052-6

FAO. (2009). Does gender make a difference in dealing with climate shifts? Research results from Andhra Pradesh, India. Gender, Equity and Rural Employment Division Economic and Social Development Department Food and Agriculture Organization of the United Nations Rome.

Goggin, C. L., \& Lester, R. J. G. (1995) Perkinsus, a protistan parasite of abalone in Australia review. Marine and Freshwater Research, 46, 639-646. http://dx.doi.org/10.1071/MF9950639

Harvell, C. D., Mitchell, C. E., Ward, J. R., Altizer, S., Dobson, A. P., Ostfeld, R. S., \& Samuel, M. D. (2002). Science, 296, 2158-2162. http://dx.doi.org/10.1126/science.1063699

IPCC. (2007). Summary for Policy Makers. In: Climate Change 2007. Mitigation. Contribution of Working Group III to the Forth Assessment Report of the Intergovernmental Panel on Climate Change. (ed. Metz B, Davidson OR, Bosch PR, Dave R, Meyer LA). Cambridge and New York: Cambridge University Press.

Jackson, C. J, \& Wang, Y. G. (1998). Modeling growth rate of Penaeus monodon Fabricus in intensively managed ponds: effects of temperature, pond age and stocking density. Aquaculture Research, 29, 27-36. http://dx.doi.org/10.1111/j.1365-2109.1998.tb01358.x

Kalirajan, K. P., \& Shand, R. T. (1989). A generalised measure of technical efficiency. Applied Economics, 21, 25-34. http://dx.doi.org/10.1080/772284229

Kasperson, R. E., Kasperson, J. X., \& Dow, K. (2001). Vulnerability, equity, and global environmental change. In: Global Environmental Risk (ed. Kasperson, J. X. \& Kasperson, R. E.). Earthscan London, pp. 247272.

Kongkeo, H., \& Davy, F. B. (2009). Backyard hatcheries and small scale shrimp and prawn farming in Thailand. In: De Silva S. S. \& Davy, F. B. (eds.) Success Stories in Asian Aquaculture, pp. 69-87. Springer-IDRCNACA, Doredrecht, The Netherlands.

Kumar, K. S. K., \& Parikh, J. (2001). Indian agriculture and climate sensitivity. Global Environmental Change, 11, 147-154. http://dx.doi.org/10.1016/S0959-3780(01)00004-8

Lal, M., Nozawa, T., Emori, S., Harasawa, H., Takahashi, K., Kimoto, M., Abe-Ouchi, A., Nakajima, T., Takemura, T., \& Numaguti, A. (2001). Future climate change: Implications for Indian summer monsoon and its variability. Current Science, 81, 1196-1207.

Liverman, D. M. (2001). Vulnerability to Global Environmental Change. In: Global Environmental Risk (ed. Kasperson, J. X. \& Kasperson, R. E.). Earthscan, London, pp. 201-216.

Meeusen, W., \& Van den Broeck, J. (1977). Efficiency Estimation from Cobb- Douglas production functions with composed error. International Economic Review, 18, 435-444. http://dx.doi.org/10.2307/2525757

MPEDA. (2006). Action plan for development of export oriented aquaculture in maritime states of India. MPEDA, Cochin, pp. 72.

MPEDA. (2010). Marine Products Export Development Authority, Cochin. Retrieved from http://www.mpeda.com/inner_home.asp?pg=trends

Muller, J. (1974). On sources on measured technical efficiency: The impact of information. American Journal of Agricultural Economics, 56, 730-738. http://dx.doi.org/10.2307/1239302

Muralidhar, M., Gupta, B. P., Jayanthi, M., \& Ponniah, A. G. (2009). Impact of extreme climatic events on brackish water aquaculture. In: Marine Ecosystems Challenges and Opportunities Book of Abstracts (ed. Vivekanandan, E.). Marine Biological Association of India, Cochin, pp. 249-250.

Muralidhar, M., Kumaran, M., Muniyandi, B., Abery, W. N., Umesh, N. R., De Silva, S. S., \& Jumnongsong, S. (2010). Perception of climate change impacts and adaptation of shrimp farming in India: Farmer focus group discussion and stakeholder workshop Report Network of Aquaculture Centers in Asia-Pacific, pp. 75.

NaCSA. (2009). Agenda for the 8th Governing Council Meeting. In: MPEDA, HO, Cochin. 
Nageswara, R. K., Subraelu, P., Rao, T. V., Malini, H. B., Ratheesh, R., Bhattacharya, S., Rajawat, A. S., \& Ajai. (2008). Sea-level rise and coastal vulnerability: an assessment of Andhra Pradesh coast, India through remote sensing and GIS. Journal of Coast Conservation, 12, 195-207. http://dx.doi.org/10.1007/s11852-009-0042-2

Nageswara, R. K., Ashokvardhan, D., \& Subraelu, P. (2007). Coastal topography and tsunami impact: GIS/GPS-based mobile mapping of the coastal sectors affected by 2004-tsunami in Krishna-Godavari delta region. Eastern Geography, 13.

Pant, G. B., Rupa, K. K., \& Borgaonkar, H. P. (1999). Climate and its long-term variability over the western Himalaya during the past two centuries. In: The Himalayan Environment (ed. by Dash SK, Bahadur J. pp. 172-184). New Delhi: New Age International (P) Limited Publishers.

Pendleton, E. A, Thieler, E. R., \& Williams, S. J. (2004). Coastal vulnerability assessment of Cape Hatteras National Seashore (CAHA) to sea level rise.

Phan, L. T., Bui, T. M., Nguyen, T. T. T., Gooley, G. J., Ingram, B. A., Nguyen, H. V., Nguyen, P. V., \& De Silva, S. S. (2009). Current status of farming practices of striped catfish, Pangasianodon hypophthalmus in the Mekong Delta, Vietnam. Aquaculture Research, 296, 227-236. http://dx.doi.org/10.1016/j.aquaculture.2009.08.017

Pillai, S. M., \& Muralidhar, M. (2006). Survey and demarcation of seawater inundated areas for eco-friendly aquaculture in Andaman and Nicobar Islands, Report submitted to Andaman and Nicobar Administration, Port Blair, Central Institute of Brackishwater Aquaculture. Chennai, p. 69.

Ponniah, A. G., \& Muralidhar, M. (2009). Research requirements to understand impact of climate change on Brackishwater aquaculture and develop adaptive measures. In: Proceedings of 96th Session of the Indian Science Congress, Part II: Session of Animal Veterinary and Fisheries Sciences, pp. 46-47.

Preston, N. P., Jackson, C. J., Thompson, P., Austin, M., Burford, M. A., \& Rothlisberg, P. C. (2001). Prawn farm effluent: Composition, origin and treatment. Fisheries Research and Development Corporation, Australia.

Rupakumar, K., Krishna, K. K., \& Pant, G. B. (1994). Diurnal asymmetry of surface temperature trends over India. Geophysical Research Letter, 21, 677-680. http://dx.doi.org/10.1029/94GL00007

Sanghi, A., \& Mendelsohn, R. (2008). The Impacts Of Global Warming On Farmers In Brazil And India. Global Environmental Change, 18, 655-665. http://dx.doi.org/10.1016/j.gloenvcha.2008.06.008

Schneider, S., Sarukhan, J., Adejuwan, J., Azar, C., Baetghen, W., Hope, C., Moss, R., Richels, R., \& van Ypersele, J. P. (2001). Overview of Impacts, Adaptation, and Vulnerability to Climate Change. In: Climate Change 2001: Impacts Adaptation, and Vulnerability (Chapter 1). Contribution of Working Group II to the Third Assessment Report of the Intergovernmental Panel on Climate Change.

Singh, N., \& Sontakke, N. A. (2002). On climate fluctuations and environmental changes of the Indo-Gangetic plains, India. Climatic Change, 52, 287-313. http://dx.doi.org/10.1023/A:1013772505484

Srivastava, H. N., Dewan, B. N., Dikshit, S. K., Rao, G. S. P., Singh, S. S., \& Rao, K. R. (1992). Decadal trends in climate over India. MAUSAM, 43, 7-20.

Timmer, C. P. (1971). Using probabilistic frontier production function to measure technical efficiency. Journal of Political Economy, 79, 776-794. http://dx.doi.org/10.1086/259787

Umesh, N. R., Mohan, A. B. C., Ravibabu, G., Padiyar, P. A., Phillips, M. J., Mohan, C. V., \& Bhat, B. V. (2009). Shrimp farmer in India: Empowering small scale farmer through a cluster-based approach. In: Success Stories in Asian Aquaculture (ed. by De Silva S. S. \& Davy, F. B. pp. 43-68). Springer-IDRC-NACA.

Unnikrishnan, A. S., Rupa Kumar, K., Fernandes, S. E., Michael, G. S., \& Patwardhan, S. K. (2006). Sea level changes along the Indian coast: observations and projections. Current Science, 90.

Vilchis, L. I., Tegner M. J., Moore, J. D., Friedman, J. D., Friedman, C. S., Riser, K. L., Robbins, T. T., \& Dayton, P. K. (2005). Ocean warming effects on growth reproduction and survivorship of southern California abalone. Ecological Applications, 15. http://dx.doi.org/10.1890/03-5326

Yadava, Y. S. (2002). Shrimp farming In India: Lessons and challenges in Sustainable Development. Aquaculture Authority News, 1, 1-4. 